\title{
Classificatory disputes and scientific controversies: society, nature, and culture in the Anthropocene
}

\author{
Disputas classificatórias e controvérsias científicas: \\ sociedade, natureza e cultura no Antropoceno
}

Felipe Barbosa Bertulucia

Leila da Costa Ferreirab

Roberto Donato da Silva Júnior ${ }^{c}$

${ }^{a}$ Master in Sociology, PhD Student, Núcleo de Estudos e Pesquisas Ambientais, Universidade Estadual de Campinas, Campinas, SP, Brazil E-mail: felipebertuluci@gmail.com

${ }^{b}$ PhD in Social Sciences, Professor, Instituto de Filosofia e Ciências Humanas, Universidade Estadual de Campinas, Campinas, SP, Brazil E-mail: leilacf@unicamp.br

'PhD in Environment and Society, Professor, Faculdade de Ciências Aplicadas, Universidade Estadual de Campinas, Limeira, SP, Brazil E-mail: robertod@unicamp.br

doi: 10.18472/SustDeb.v12n2.2021.34395

\begin{abstract}
In general, the idea of Anthropocene refers to the set of socio-historical, ecological, economic, and technological transformations responsible for configuring a new stage of regulation and evolution of the planetary geological system. From its original proposition in the 2000s, this notion gained increasing repercussion, mobilizing different positions in multiple fields of scientific knowledge. This article aims to develop a critical analysis of some of the main concepts found in such debates, from the mobilization of three fundamental analytical categories: the concepts of Society, Nature, and Culture. In methodological terms, this is a literature review article based on qualitative and non-systematic bibliographic research. The analysis undertaken here indicates how the different approaches mobilized by the driving idea of Anthropocene result in theoretical movements that redefine the relationships between agency, structure, and social change in the historical context of modern industrial societies.
\end{abstract}

Keywords: Anthropocene. Sustainability. Social Theory. Climate Change.

\section{RESUMO}

De maneira geral, a ideia de Antropoceno faz referência ao conjunto de transformações sóciohistóricas, ecológicas, econômicas e tecnológicas responsáveis por configurar uma nova etapa de regulação e evolução do sistema geológico planetário. A partir de sua proposição original nos anos 
2000, essa noção ganhou repercussão cada vez maior, mobilizando posicionamentos díspares em múltiplos campos do conhecimento científico. Este artigo tem como objetivo desenvolver análise crítica a respeito de algumas das principais concepções encontradas em tais debates, a partir da mobilização de três categorias analíticas fundamentais: os conceitos de Sociedade, Natureza e Cultura. Em termos metodológicos, trata-se de artigo de revisão da literatura, a partir de pesquisa bibliográfica de caráter qualitativo e não sistemático. A análise empreendida indica como as diferentes abordagens mobilizadas pela ideia-força de Antropoceno implicam movimentos teóricos de redefinição das relações entre agência, estrutura e mudança social no contexto histórico das sociedades industriais modernas.

Palavras-chave: Antropoceno. Sustentabilidade. Teoria Social. Mudanças Climáticas.

\section{INTRODUCTION}

Since its presentation in the early 2000s, the idea of Anthropocene has gained enormous repercussion and popularity in scientific debate forums, as well as in cultural and media spaces of social communication (CRUTZEN, 2002; CRUTZEN; STOERMER, 2000; MONASTERSKY, 2015; STEFFEN et al., 2011, 2015; TRISCHLER, 2016). In academic terms, this importance is expressed, for instance, in the release and publication of scientific journals exclusively dedicated to the theme: "The Anthropocene," "Elementa: Science of the Anthropocene," and "The Anthropocene Review". In addition, artists and architects have responded to the implications of this discussion in their professional practice, poets and writers translate their concepts into literary productions and invite academics and ecocritics to reflect on similar cultural translation practices (LEWIS; MASLIM, 2015; TRISCHLER, 2016).

In general, the idea of Anthropocene refers to the set of social, historical, ecological, economic, political, cultural, and technological transformations responsible for configuring a new stage of regulation and evolution of the planetary geological system. Its fundamental premise is based on observations, measurements, trend studies, and records that indicate the occurrence and intensification of multiple processes of imbalance, exploitation, and disturbance in the dynamics of ecosystem regulation at the most different planetary scales (ARTAXO, 2014; CRUTZEN, 2002; CRUTZEN; STOERMER, 2000; ROCKSTRÖM et al., 2009; STEFFEN et al., 2011, 2015; ZALASIEWICZ et al., 2017, 2018). In contrast to the Holocene period, the human species would come to be seen as a force acting on a geological scale, from its intensive activities and interactions with the biophysical environment. In this sense, anthropic actions become so broad and deep that they assume characteristics of rivalry to the great forces of Nature, pushing the Earth system towards the uncertain and unknown (STEFFEN; CRUTZEN; MCNEILL, 2007).

As such, the discussion around an Age of Humans seems to operate from the split established between society (or culture) and nature (or biophysical environment) (CHAKRABARTY, 2009, 2018; LATOUR, 1994, 2012, 2014, 2017; LEWIS; MASLIM, 2015; TRISCHLER, 2016). In other words, it is as if the capacity for human organization and activity assumed a position of independence from the limitations previously established by the physical, biological, and natural dimensions that structured human existence. From an increasingly specialized and concentrated power of manipulation and transformation, humanity re-articulates its place in the landscape of the evolution of species, often placing itself in a position of domination and/or control of the forces, processes, and phenomena typically characterized as natural (CRUTZEN, 2002, 2006; STEFFEN; CRUTZEN; MCNEILL, 2007; STEFFEN et al., 2011, 2015). In this sense, the scientific debate revolves around understanding the characteristics, magnitude, dimensions, and scope of the observed (and projected) transformations, to establish the "balance of forces" between two competing antagonistic powers. 
Based on such general problems, this article aims to develop a critical analysis of some of the main approaches and concepts found in the scientific literature on the Anthropocene. More precisely, we seek to investigate how discussions around the concept, originally circumscribed to its geological and biophysical sense, reach new dimensions and mobilize theoretical re-elaborations within the scope of social theory and in interdisciplinary domains of knowledge. In this sense, three analytical categories stand out: the concepts of Society, Nature, and Culture, as well as the relationships conceived around their interactions. Our central question is: how do theoretical-scientific discussions about the Anthropocene collaborate to redefine categories central to understanding modern industrial societies, such as the concepts of Society, Nature, and Culture?

In methodological terms, this study is defined as a literature review article, based on non-systematic bibliographic research (MARCONI; LAKATOS, 2017; MEDEIROS; TOMASI, 2016). We justify the nonsystematic nature of the review undertaken based on the originality of the debates around the object under analysis, as well as the exponential character associated with the volume of publications on the subject in the past fifteen years (BRONDIZIO et al., 2016). In this sense, we privilege a qualitative research approach, recognizing the advantages and limitations arising from such a choice, in aspects such as depth of analysis and absence of statistical representativeness (MARCONI; LAKATOS, 2017).

Regarding the criteria for identifying and selecting references, we start with the pioneering publications of Crutzen (2002) and Crutzen and Stoermer (2000), in addition to the studies carried out by the Anthropocene Working Group (AWG) within the scope of the International Commission on Stratigraphy (ICS). Based on this, we searched for the term "Anthropocene" in the Google Scholar and Scopus databases and selected publications with the greatest impact and relevance, in terms of the number of citations and topicality. In addition, we consider the relevance of the work analyzed for the objectives of this article, especially from the mobilization of the fundamental analytical categories of Society, Nature, and Culture within the scope of social theory and interdisciplinary domains of knowledge.

The article is divided into three sections. In the first part, we present some of the main arguments, perspectives, and dissonant points of view constituting the scientific literature about the definition of a new geological period named Anthropocene, as well as its fundamental characteristics, and the appropriate markers for establishing its starting date. Next, we discuss the theoretical-epistemological assumptions and reverberations present in the most prominent propositions about the concept, particularly from the work of the Anthropocene Working Group (AWG). In the third part, we expand the discussion about the theoretical, cultural, political, social, and epistemological developments involved in the debates about the Anthropocene, highlighting the issues pertinent to the theoretical relationships between Nature, Culture, and Society in the conditions of modernity. In the conclusion, we point out the potentialities identified from the use of the Anthropocene idea, based on the analysis undertaken of the theoretical-scientific debates and the observed capacity of the concept to reverberate profound transformations (and metamorphoses) constitutive of modern industrial societies.

\section{SCIENTIFIC CONTROVERSIES ABOUT THE ANTHROPOCENE}

The idea that the human species exerts significant changes and impacts on the natural environment, throughout virtually all its evolutionary history, is widely recognized and discussed in the scientific literature. Such recognition of the effects of anthropic actions on terrestrial landscapes, on the composition and diversity of biological species, on the disturbance of biogeochemical and ecological dynamics is seen as a fundamental precursor to the contemporary concept of Anthropocene, based on the intellectual production of authors from the $19^{\text {th }}$ and beginning of the $20^{\text {th }}$ centuries (CRUTZEN, 2002; CRUTZEN; STOERMER, 2000; HAMILTON; GRINEVALD, 2015; LEWIS; MASLIM, 2015; STEFFEN et al., 2011; ZALASIEWICZ et al., 2018). However, the proposition of a new geological period in the history of planet Earth, characterized by the large-scale performance of humanity as a factor of unprecedented degradation and disturbance, represents a radical breaking point in scientific and intellectual terms (HAMILTON; GRINEVALD, 2015). 
The formal recognition of the Anthropocene period as the most recent division on the geological time scale depends on a rigorous process of gathering evidence, establishing measurements and correlations, and, finally, on expressive approval by the community of scientific experts in the fields of geosciences, geology, and associated disciplines. The work undertaken by the Anthropocene Working Group (AWG) in this regard is institutionally linked to the Subcommission on Quaternary Stratigraphy of the International Commission on Stratigraphy (ICS). Thus, the proposal in favour of the official establishment of the geological period of the Anthropocene requires a written, robust, and consistent formulation from the AWG and a critical evaluation in the different institutional instances listed here. If approved by a margin greater than or equal to $60 \%$ of the voting members within the scope of the Subcommittee on Quaternary Stratigraphy, the proposal proceeds for consideration by the ICS executive council and the chairs of the sixteen subcommittees that integrate such entity. If approved again by a margin of $60 \%$, ratification is finally required from the executive committee of the International Union of Geological Sciences (IUGS), the highest decision-making agency (FINNEY; EDWARDS, 2016; LEWIS; MASLIM, 2015; TRISCHLER, 2016; ZALASIEWICZ et al., 2017, 2018).

We note, therefore, the complexity and scope of the steps related to the decision-making process of scientific controversies and disputes, as is the case with the formal establishment of the Anthropocene. Within this specific issue, some perspectives and points of view stand out, calling into question the usefulness of the scientific definition regarding the Anthropocene, its precision and conceptual rigour, as well as the ideological motivations and/or political interests involved. In this sense, among the proposals in dispute, some questions emerge pointing to the absence of consistent technical criteria, which are indispensable to the consolidated scientific practice of geological dating. With this, some authors assertively ask about the appropriate location of discussions about the Anthropocene in the context of popular culture, to the detriment of serious scientific investigation (AUTIN; HOLBROOK, 2012); the eminently political character inscribed in scientific and intellectual movements that seek to affirm the recognition of the concept; and the anthropocentric dimension that can be identified in the discussions involving the Anthropocene (FINNEY, 2014; FINNEY; EDWARDS, 2016). As we will see, such questions can be resumed and deepened when we consider the epistemological, social, political, and cultural developments of the reported disputes (BECK, 1992, 1997, 2018; CHAKRABARTY, 2009, 2018; LATOUR, 1994, 2012, 2017).

The classificatory and conceptual disputes also permeate the debates established among the defenders of the geological concept of the Anthropocene, particularly around the description of its main characteristics and the definition of a starting date for the period. In their influential bibliographic review on the topic published in the journal Nature, Lewis and Maslim (2015) list nine potential candidates discussed in the scientific literature for characterizing and demarcating the beginning of the Anthropocene. They are: megafauna extinction processes that occurred in different geographic locations throughout human history, between 50,000 to 10,000 years BP (before present ${ }^{1}$ ); the origin of the practices of agriculture, livestock, and permanent human settlements about 11,000 years BP; the intensification and increase of the area converted to agricultural activities ( 8,000 years BP to date); the extensive production of rice crops and domesticated ruminant animals, with the concomitant release of large amounts of methane $(\mathrm{CH} 4)$ into the atmosphere $(\sim 6,500$ years BP to date); the formation of soils from specifically anthropogenic actions/pressures ( $3,000-500$ years $B P)$; the historic process of collision between the European Old World and the New World discovered in the Americas ('Orbis hypothesis'); the socio-political, economic, and technological transformations arising from the Industrial Revolution, from the end of the 18th century in England; the detonation of thousands of nuclear artifacts, as tests, in the context of the Cold War; and the large-scale development and production of polluting and environmentally persistent chemicals (LEWIS; MASLIM, 2015)².

Each of these propositions is based on the geological, archaeological, and historical reconstruction of impacts arising from human activities in biogeochemical cycles and planetary ecosystem processes, as well as the observation and analysis of anthropogenic dynamics of exploitation, degradation, and disturbance of the Earth system. Depending on the characterization established, regarding the fundamental 
rupture milestones towards a new geological period, different theoretical, cultural, and epistemological implications and developments are possible. In the words of Lewis and Maslim (2015, p. 178), "the event or date chosen as the inception of the Anthropocene will affect the stories people construct about the ongoing development of human societies". In the case of the 'Orbis hypothesis,' defended by such authors as one of the most appropriate candidates, its recognition would imply that colonialism, global trade, and the widespread use of coal started the Anthropocene, with broader repercussions for social issues, such as the unequal distribution of power between human groups, economic growth, the impacts of globalized trade, and modern dependence on fossil fuels (LEWIS; MASLIM, 2015) .

\section{THE HUMAN SPECIES IN THE ANTHROPOCENE: POWER, DOMINATION AND CONTROL}

The original formulations of Crutzen (2002) and Crutzen and Stoermer (2000), which inaugurated contemporary discussions on the Anthropocene, set the beginning of such a period at the advent of the Industrial Revolution in the late $18^{\text {th }}$ century. Admitting that the choice of a specific date to mark the origin of the new geological age is relatively arbitrary, the authors argue that the anthropogenic impacts and effects arising from the transformations that took place amid the Industrial Revolution are global, comprehensive, intensive, profound, and lasting. In this sense, humanity starts to place itself as a force acting on a geological scale, and its capacities to modify the biosphere and the Earth system operate in magnitudes comparable to the great forces of Nature. Just as the consequences of natural phenomena, such as large volcanic eruptions, asteroid impacts, changes in the Earth's orbit, and movements of tectonic plates, can result in profoundly different environmental conditions for thousands or millions of years (and in many cases, irreversible), human activities in the Anthropocene exert planetary pressures and impacts of a similar order of magnitude (CRUTZEN, 2002; CRUTZEN; STOERMER, 2000; STEFFEN; CRUTZEN; MCNEILL, 2007). According to Crutzen and Stoermer (2000),

Considering these and many other major and still growing impacts of human activities on earth and atmosphere, and at all, including global, scales, it seems to us more than appropriate to emphasize the central role of mankind in geology and ecology by proposing to use the term "Anthropocene" for the current geological epoch. The impacts of current human activities will continue over long periods. (p. 17)

Here we observe the basic interconnection between the strictly scientific sense of the concept of Anthropocene and its broader cultural dimensions. Far from signifying a problematic and undesirable derivation, the mutual dependence between the spheres of scientific activity, political action, and cultural representation constitutes fundamental data that characterizes the discussions on the theme. As Beck $(1992,1997)$ observes, regarding the process of reflexive modernization of industrial societies, the spheres of action of politics, science, and society start to be influenced indelibly, to the point that it is no longer possible to establish clear boundaries between each of these spheres. In simplified terms, these are the phenomena of the politicization of science and the scientification of politics, in which new forms of decision and participation are generated from mechanisms of subpolitics (BECK, 1992, 1997, 2018).

In the case of the debates about the Anthropocene, the formal establishment of the new geological period would mark a fundamental change in the theoretical-conceptual, cultural, ontological, and epistemological relationships between the human species and the Earth system (CHAKRABARTY, 2009, 2018; LATOUR, 2014; LEWIS; MASLIM, 2015). This is because, as pointed out above, human activities would be directly recognized as the dominant cause of most contemporary environmental changes, with their impacts and repercussions on the very dynamics of functioning of the planetary biogeochemical, natural, and evolutionary processes. Such a condition would place humanity, in one way or another, as an active and self-conscious agent, responsible for the operation of the support systems of the very possibilities of life (STEFFEN; CRUTZEN; MCNEILL, 2007). A similar perspective is also present in an editorial text published by the journal Nature in 2011, in which it is noted that the official recognition of the Anthropocene would invite 
interdisciplinary research in science and encourage an important mentality, not only to fully understand the ongoing transformations but also act to control them. Thus, "the first step is to recognize, as the term Anthropocene invites us to do, that we [human beings] are in the driver's seat" (NATURE, 2011, p. 254).

According to this perspective, the observation of the speed, magnitude, and intensity of deleterious anthropogenic changes in global environmental conditions results in the need for the human species to assume its position of responsibility before the impacts generated and the possible existing solutions. Hence, three possibilities for social, political, and philosophical responses about the transformations in question arise business-as-usual, in which the economic system and social institutions continue to operate according to the same fundamental dynamics that originated the Anthropocene period; mitigation, an approach based on the recognition of growing risks and threats, which proposes that human societies should act to reduce their intensive pressures on the Earth system; and geoengineering, which brings together proposals for the active intervention of the human species on the biophysical, chemical, and ecological processes of the planet, to reverse, reorient, and control the trends of environmental imbalance and disturbance (ROCKSTRÖM et al., 2009; STEFFEN; CRUTZEN; MCNEILL, 2007; STEFFEN et al., 2011, 2015).

Regarding geoengineering options, we note that this is a highly controversial debate full of ethical, social, political, legal, and normative questions (CRUTZEN, 2002, 2006; STEFFEN; CRUTZEN; MCNEILL, 2007; VAUGHAN; LENTON, 2011). This is because such discussions involve broad and deep considerations about the relationships established between human societies and the natural environment, in theoretical, cultural, and epistemological terms. Taking as an example the issue of climate change and global warming caused by anthropic actions, we find geoengineering propositions that suggest the possibility of large-scale technical/technological interventions in the planetary climate system, to fight and reverse the ongoing harmful changes (CRUTZEN, 2006; VAUGHAN; LENTON, 2011).

This attitude of optimism and confidence in the ability of the human species to use its creativity, scientific knowledge, and technological innovations to overcome barriers, limitations, and imbalances arising from nature is synthesized, in cultural terms, in the defence of the idea of a "Good Anthropocene". According to this conception, even in the face of the profound global environmental changes that exist, human systems are prepared to adapt and even thrive on the hottest and least bio-diverse planet that we, as humanity, are building. "Indeed, the history of human civilization might be characterized as a history of transgressing natural limits and thriving" (ELLIS, 2011, p. 42). In this sense, the potential to simultaneously mitigate climate change, preserve nature, and alleviate basic material needs globally lies with the socioeconomic processes and technological capabilities of the human species as a whole (ASAFU-ADJAYE, 2015; ELLIS, 2011, 2015).

\section{SOCIAL THEORY AND ENVIRONMENT: CRITICAL PERSPECTIVES ON THE ANTHROPOCENE}

As we have highlighted, discussions about the concept of Anthropocene assume developments that extend far beyond controversies and strictly scientific debates, involving central aspects related to the cultural, social, philosophical, and political dimensions of modern societies. Based on the propositions established by Crutzen (2002) and Crutzen and Stoermer (2000), the theme aroused increasing interest and participation, both from the academic community associated with the areas of social sciences and humanities and from the wider lay public, by multiple social media (BAUER; ELLIS, 2018; CHAKRABARTY, 2018; LATOUR, 2014, 2017; TRISCHLER, 2016). These are different spheres of definition and meaning, which are inextricably related, making it very difficult to try to isolate the contributions, references, and conceptualizations specific to each of these theoretical-epistemological fields (BECK, 1992, 1997, 2018; LEWIS; MASLIM, 2015; TRISCHLER, 2016). The Anthropocene Working Group (AWG) itself, responsible for the official proposal of the geological concept, is composed of archaeologists, historians, geographers, and even a lawyer (ZALASIEWICZ et al., 2018). 
In the scope of the social sciences and humanities, the idea of Anthropocene has received criticism from the broadest and most diversified trends, as well as supporters and followers. In the words of Moore (2016), despite its weaknesses and gaps, the concept of Anthropocene is "the most influential concept in environmental studies over the past decade" (MOORE, 2016, p. 2). In terms of critical perspectives, we can illustrate the wealth of theoretical and conceptual positions from the myriad of nomenclatures suggested as alternatives: instead of Anthropocene, we have propositions such as Capitalocene, Plantationocene, Econocene, Carbocene, Thantocene, Chthulucene, Technocene, Manthropocene, among many others ${ }^{4}$. Within the scope of this article, we direct our attention to just a few of these theoretical contributions present in discussions about the concept, especially those regarding the relationships conceived between Nature (Environment) and Society (Culture) in the conditions of modernity.

The first point of criticism that we would like to highlight refers to the predominant tendency, among the main formulations of the Anthropocene, to consider "humanity" acting as a single, cohesive, and homogeneous agent. This is the main argument supported by Malm and Hornborg (2014), in contrast to the standard narrative that interprets human activities and their impacts on the Earth system from the general category of the human species. Such a discursive movement, according to the authors, proves to be analytically flawed and tends to lead discussions towards mystification and political paralysis. This is because the consideration of global environmental changes, particularly climate change, under the bias of "humanity" as a category of explanation, hides fundamental intraspecific inequalities while naturalizing eminently social, historical, economic, and political processes. "Realising that climate change is 'anthropogenic' is really to appreciate that it is sociogenic" (MALM; HORNBORG, 2014, p. 66, italics from authors). Thus, important questions related to categories of analysis such as power, culture, capital, social classes, inequality, and mode of production comprise a first-rate explanatory axis (BAUER; ELLIS, 2018; CHAKRABARTY, 2018; HARAWAY, 2015, 2016; LATOUR, 2014; MALM; HORNBORG, 2014).

Such critical positioning is at the base of the proposition of the term Capitalocene, in contrast to the formulations in favour of the recognition of the Anthropocene. Thus, according to this perspective, an accurate understanding of the new geological period in which we live requires recognizing the decisive factors that gave rise to, sustain, and promote the profound ecological and environmental transformations observed on the planet and in the forms of life that inhabit it. According to Moore $(2015,2016)$, one must locate, in the logic of the formation, structuring, and functioning of capitalism, the roots of contemporary systemic crises, both social and ecological. Under this key, capitalism can be understood as a way of organizing nature as a whole, configuring itself according to a world ecology that integrates capital accumulation, the search for power, and the co-production of nature in successive historical formations. In this sense, the widespread notion of Anthropocene raises central questions that it is not able to answer (MOORE, 2016).

Another critical point concerns the identification of a markedly anthropocentric character in the debates about the Anthropocene. In the opinion of some authors, this anthropocentric stance is expressed, for example, in the unprecedented suggestion to characterize and officially name a specific geological period based on the activities performed by a single biological species, such species being precisely ours (FINNEY, 2014; FINNEY; EDWARDS, 2016). Among the specialities of the social sciences and humanities, perspectives aligned to the so-called neo-materialism point out that the views related to the concept of Anthropocene, both optimistic and pessimistic, operate from the conventional modernist belief of separation between humans (and their cultural domain) and the natural material world. Thus, as soon as we start talking about the human species as a 'geological actor' that is leading us into a new 'Human Age,' "we begin to overestimate human power and agency, tending towards a celebratory stance even when the intent is to be critical" (LECAIN, 2015, p. 4). According to LeCain (2015), therefore, the concept of Anthropocene suffers from a serious flaw, namely: its fundamentally anthropocentric focus of the biogeochemical phenomena that it proposes to register ${ }^{5}$. 
This leads us to the last point that we would like to address, concerning the cultural, political, epistemological, and ontological developments inherent to debates about the Anthropocene. It is precisely the fundamental modern distinction between the fields of Nature, on the one hand, and Society (Culture), on the other. Latour $(1994,2012,2017)$ can be pointed out as one of the contemporary social theorists who best synthesized the analyses on such a historical process of cultural, intellectual, and epistemological split, as well as their breaking points and philosophical and social implications. In his study, the question of agency appears as a privileged topic of investigation, putting many of the central assumptions and axioms that constitute hegemonic modes of thought in modern Western societies on hold. Among these basic assumptions, the author draws attention to the progressive breakdown of a "scientific worldview" that established the existence of an objective material reality consisting of mere physical, passive, and inanimate objects (LATOUR, 1994, 2012, 2017).

In the context of discussions on the new geological period of the Anthropocene, Bruno Latour's contributions lead us to broad, deep, and fundamental reflections. Addressing specifically the problem of agency in the Anthropocene, Latour (2014) observes that it is impossible to understand the current global environmental transformations and changes from a distant and objective position as if it were only dealing with 'information' coming from the material natural world and from the sciences responsible for investigating it. "There is no distant place anymore. And along with distance, objectivity is gone as well; or at least, an older notion of objectivity that was unable to take into account the active subject of history" (LATOUR, 2014, p. 2). Thus, one must recognize the unfolding of a process of redistribution of the roles of subject and agency in the conditions of modernity under the Anthropocene, in which the human species is displaced from its dreams of control, power, and domination over the wild world of nature. Under the threat of global warming, we can notice the occurrence of a curious inversion in the Western philosophical perspective: human history becomes paralyzed and frozen, while natural history is taking a frantic and fast pace (LATOUR, 2014, 2017).

Chakrabarty $(2009,2018)$, in contributions that have become central to the discussions on the Anthropocene among the social sciences and humanities, reinforces the reading that the new geological period is marked by the collapse of the old humanist distinction established between natural history and human history. In this sense, the challenge imposed by this new socio-historical configuration lies in integrating, within the same theoretical, cultural, epistemological, and ontological framework, two widely different registers: the way of thinking based on human history (World History), with its categories such as empires, colonies, classes, institutions, nations; and the way of thinking situated on the scale of planetary geological and biogeochemical processes (Earth History). In other words, "the geologic now of the Anthropocene has become entangled with the now of human history" (CHAKRABARTY, 2009, p. 212). For social theorists and humanists living in this new geo-historical period, issues involving the history of volcanoes, mountains, oceans, and tectonic plates have become as routine, in the exercise of critical and analytical thinking, as questions about global capital and the necessary inequalities of the world it produced (CHAKRABARTY, 2018; LATOUR, 2014).

\section{FINAL CONSIDERATIONS}

The idea of Anthropocene, more than just a concept restricted to the scientific community of experts in geosciences, is part of a broad space for discussion and reflection, which takes as its main object of analysis the intense anthropogenic impacts on the dynamics of planetary ecosystem regulation and functioning. Thus, we note the predominance of significant conceptual controversies, classificatory disputes, different positions and political questions about the terms, definitions, and characteristics associated with the recognition of a new geological period in the history of planet Earth. In such debates, the technical, scientific, political, cultural, and normative dimensions are deeply entangled and interconnected, in the wake of more comprehensive socio-historical processes, which concern the configurations of modernity in Western industrial societies (BECK, 1992, 1997, 2018; HARAWAY, 2015, 2016; LATOUR, 1994, 2012, 2017; MOORE, 2015, 2016). 
Anyway, the observed reality concerns the registration of the multiple deleterious effects arising from human activities in the most varied dimensions and phenomena of the biosphere and the Earth system (ARTAXO, 2014; CRUTZEN, 2002; CRUTZEN; STOERMER, 2000; ROCKSTRÖM et al., 2009; STEFFEN et al., 2011, 2015; ZALASIEWICZ et al., 2017, 2018). In most of these parameters, human pressures and impacts have intensified, as we collectively advance within the scope of the Anthropocene. In this regard, the agency issue and the resulting theoretical, cultural, and political developments are of decisive importance. Whether from propositions that recognize the human species acting as a cohesive geological force in interaction with the Earth system, or from criticism to a unifying vision of humanity that disregards inequalities in power and capital, or even under indications that the essential political task is to distribute the agency in the most different and broad ways possible, what is observed is a process of basic restructuring of the dynamics of social ordering in the Anthropocene. This is a historical moment in which old conceptual categories and conventional modes of thought and cognition no longer meet the pressing needs of a time marked by urgency and acceleration.

Thus, we conclude that the notion of Anthropocene is presented as a driving idea 6 with enormous potential for the efforts to understand, analyze, and act in the 21st century's historical reality. At the same time that it seeks to constitute a rigorous scientific concept, the idea of Anthropocene mobilizes a wide range of cultural, political, ecological, economic, and technological transformations, changes, and metamorphoses responsible for configuring the emergence of new socio-historical conditions and possibilities. In proposing, in his latest work, the notion of "metamorphosis" as an explanatory key to contemporary processes of social change, Beck (2018) indicates that "metamorphosis implies a much more radical transformation, in which the old certainties of modern society are disappearing and something entirely new emerges" (BECK, 2018, p. 11). Before such a political and existential condition, the author recalls, it is necessary to redefine our way of being in the world, of thinking about the world, of imagining and doing politics, recognizing the profound consequences and implications of living in the era of side effects.

In theoretical-methodological terms, this means locating the discussions and debates about the Anthropocene in an eminently broad and plural field of conceptual possibilities and definition relationships. The different ways of conceiving the relationships between Nature, Society, and Culture mobilized by the driving idea of Anthropocene thus require different movements for redefining the interactions between agency, structure, and social change in the socio-historical context of modern industrial societies. Analytical categories dear to the intellectual traditions consolidated in social theory, such as class, nation, and state, lose explanatory power before new theoretical and practical references, such as the "world," the "planet," and "humanity". As we have noted, the notion of Anthropocene represents a decisive contribution to the task of navigating the stormy seas of the profound changes and transformations of a world in metamorphosis.

\section{ACKNOWLEDGMENTS}

The authors thank Capes (Coordenação de Aperfeiçoamento de Pessoal de Nível Superior), Fapesp (Fundação de Amparo à Pesquisa do Estado de São Paulo - process n.19/14867-2), for the financial support to our research projects, and Espaço da Escrita - Pró-Reitoria de Pesquisa - Unicamp, for the language services provided. Also, we would like to thank the reviewers for their thoughtful comments and suggestions made about our manuscript. 


\section{NOTES}

1. Before present (BP) - indicates the systematization of the time count for geological events, in which the 'present' is defined as the 1950 calendar date. Cf. Lewis and Maslim (2015).

2. Cf. Bauer and Ellis (2018), Ellis (2011), Ruddiman (2003, 2013), Steffen, Crutzen, and McNeill (2007), Steffen et al. (2011, 2015), Trischler (2016), Waters et al. (2016), and Zalasiewicz et al. $(2017,2018)$.

3. Cf. LeCain (2015), Malm and Hornborg (2014), and Moore (2015, 2016).

4. Cf. Bauer and Ellis (2018), Chakrabarty (2018), Haraway (2015, 2016), Latour (2017), LeCain (2015), Malm and Hornborg (2014), and Moore $(2015,2016)$.

5. The debate regarding human performance in the configuration of the landscape and the biodiversity of different locations has multiple perspectives and different analytical axes. In this regard, we must mention the rich contribution provided by Archaeology in the discussion of such historical processes of fundamental interconnection between social, cultural, biological, and ecological dimensions. There is a whole field of research and analysis, called Historical Ecology, which has recently turned to the consideration of similar problems, from a very innovative and thought-provoking perspective. Cf. Balée $(2006,2008)$, Neves and Petersen (2006), Rival (2006), and Roosevelt (2013).

6. By "driving idea", we mean the category of analytical concepts that unfold in multiple perspectives, approaches, and theoretical orientations, often conflicting with each other. At the same time, they are concepts that imply normative, ethical, and political reference points that are intended to be common and consensual. The idea of sustainable development can be considered a paradigmatic example of a similar conceptual category (FERREIRA, 2006; VEIGA, 2008). In addition, political-normative concepts such as "freedom," "democracy," and "justice" can also be understood from this perspective (MEADOWCROFT, 2007).

\section{REFERENCES}

ARTAXO, P. Uma nova era geológica em nosso planeta: o Antropoceno? Revista USP, n. 103, p. 13-24, 2014. Available from: https://doi.org/10.11606/issn.2316-9036.v0i103p13-24/. Access on: Sep. 26, 2020.

ASAFU-ADJAYE, J. et al. An ecomodernist manifesto. 2015. Available from: http://www.ecomodernism.org/. Access on: Jul. 18, 2020.

AUTIN, W. J.; HOLBROOK, J. M. Is the Anthropocene an issue of stratigraphy or pop culture? GSA Today, v. 22, n. 7, p. 60-61, 2012. Available from: https://www.geosociety.org/gsatoday/archive/22/7/abstract/i1052-5173-227-60.htm. Access on: Sep. 26, 2020.

BALÉE, W. The research program of historical ecology. Annual Review of Anthropology, v. 35, p. 75-98, 2006. Available from: https://doi.org/10.1146/annurev.anthro.35.081705.123231. Access on: Sep. 26, 2020.

BALÉE, W. Sobre a indigeneidade das paisagens. Revista de Arqueologia, v. 21, n. 2, p. 9-23, 2008. Available from: https://doi.org/10.24885/sab.v21i2.248. Access on: Sep. 26, 2020.

BAUER, A. M.; ELLIS, E. C. The Anthropocene Divide. Current Anthropology, v. 59, n. 2, 2018. Available from: https://doi.org/10.1086/697198. Access on: Sep. 26, 2020.

BECK, U. Risk Society: towards a new modernity. London: Sage, 1992.

BECK, U. A reinvenção da política: rumo a uma teoria da modernização reflexiva. In: BECK, U.; GIDDENS, A.; LASH, S. Modernização reflexiva: política, tradição e estética na ordem social moderna. São Paulo: Editora da Universidade Estadual Paulista, 1997.

BECK, U. A metamorfose do mundo: novos conceitos para uma nova realidade. Rio de Janeiro: Zahar, 2018. E-book. ISBN 9788537817490. Available from: https://integrada.minhabiblioteca.com.br/books/9788537817490. Access on: Sep. 14, 2020. 
BRONDIZIO, E. S. et al. Re-conceptualizing the Anthropocene: a call for collaboration. Global Environmental Change, v. 39, p. 318-327, 2016. Available from: https://doi.org/10.1016/j.gloenvcha.2016.02.006. Access on: Mar. 24, 2021.

CHAKRABARTY, D. The climate of history: four theses. Critical inquiry, v. 35, n. 2, p. 197-222, 2009. Available from: https://www.jstor.org/stable/10.1086/596640. Access on: Sep. 26, 2020.

CHAKRABARTY, D. Anthropocene time. History and Theory, v. 57, n. 1, p. 5-32, 2018. Available from: https://doi. org/10.1111/hith.12044. Access on: Sep. 26, 2020.

CRUTZEN, P. Geology of mankind: the Anthropocene. Nature, v. 415, p. 23, 2002. Available from: https://www. nature.com/articles/415023a. Access on: Sep. 26, 2020.

CRUTZEN, P. Albedo enhancement by stratospheric sulfur injections: a contribution to resolve a policy dilemma? Climatic change, v. 77, n. 3-4, p. 211, 2006. Available from: https://doi.org/10.1007/s10584-006-9101-y. Access on: Sep. 26, 2020.

CRUTZEN, P.; STOERMER, E. The Anthropocene. IGBP newsletter, 41. Royal Swedish Academy of Sciences, Stockholm, Sweden, 2000.

ELLIS, E. The planet of no return: human resilience on an artificial Earth. Breakthrough Journal, v. 2, p. 39-44, 2011.

ELLIS, E. The Used Earth: embracing our history as transformers. In: MÖLLERS, N.; SCHWÄGERL, C.; TRISCHLER, H. (ed.). Welcome to the Anthropocene. The Earth in Our Hands. Munich: Deutsches Museum, p. 52-55, 2015.

FERREIRA, L. da C. Ideias para uma Sociologia da Questão Ambiental no Brasil. São Paulo: Annablume, 2006.

FINNEY, S. C. The "Anthropocene" as a ratified unit in the ICS International Chronostratigraphic Chart: fundamental issues that must be addressed by the task group. In: WATERS, C. N. et al. (ed.). A Stratigraphical Basis for the Anthropocene. The Geological Society. London: special publication 395, p. 23-28, 2014. Available from: https:// doi.org/10.1144/SP395.9. Access on: Sep. 26, 2020.

FINNEY, S. C.; EDWARDS, L. E. The "Anthropocene" epoch: scientific decision or political statement? Gsa Today, v. 26, n. 3, p. 4-10, 2016. Available from: https://www.geosociety.org/gsatoday/archive/26/3/article/i1052-517326-3-4.htm. Access on: Sep. 26, 2020.

HAMILTON, C.; GRINEVALD, J. Was the Anthropocene anticipated? The Anthropocene Review, v. 2, n. 1, p. 59-72, 2015. Available from: https://doi.org/10.1177/2053019614567155. Access on: Sep. 26, 2020.

HARAWAY, D. Anthropocene, capitalocene, plantationocene, chthulucene: making kin. Environmental humanities, v. 6, n. 1, p. 159-165, 2015. Available from: https://doi.org/10.1215/22011919-3615934. Access on: Sep. 26, 2020.

HARAWAY, D. Staying with the trouble: anthropocene, capitalocene, chthulucene. In: MOORE, J. W. (ed.). Anthropocene or Capitalocene? Nature, History, and the Crisis of Capitalism. Oakland, CA: PM Press, p. 34-76, 2016.

LATOUR, B. Jamais Fomos Modernos: ensaio de antropologia simétrica. Rio de Janeiro: Editora 34, 1994.

LATOUR, B. Reagregando o social: uma introdução à teoria do Ator-Rede. Salvador, Bauru: Edufba, Edusc, 2012.

LATOUR, B. Agency at the Time of the Anthropocene. New literary history, v. 45, n. 1, p. 1-18, 2014. Available from: https://muse.jhu.edu/article/543416. Access on: Sep. 26, 2020.

LATOUR, B. Facing Gaia: eight lectures on the new climatic regime. Cambridge: Polity, 2017. 
LECAIN, T. Against the Anthropocene. A neo-materialist perspective. International journal for history, culture and modernity, p. 1-28, 2015. Available from: https://scholarworks.montana.edu/xmlui/handle/1/9310. Access on: Sep. 26, 2020.

LEWIS, S.; MASLIN, M. Defining the Anthropocene. Nature, v. 519, n. 7542, p. 171-180, 2015. Available from: https://doi.org/10.1038/nature14258. Access on: Sep. 26, 2020.

MALM, A.; HORNBORG, A. The geology of mankind? A critique of the Anthropocene narrative. The Anthropocene Review, v. 1, n. 1, p. 62-69, 2014. Available from: https://doi.org/10.1177/2053019613516291. Access on: Sep. 26, 2020.

MARCONI, M. de A.; LAKATOS, E. M. Metodologia do trabalho científico: projetos de pesquisa / pesquisa bibliográfica / teses de doutorado, dissertações de mestrado, trabalhos de conclusão de curso. 8. ed. São Paulo: Atlas, 2017.

MEADOWCROFT, J. Who is in Charge here? Governance for Sustainable Development in a Complex World. Journal of Environmental Policy and Planning, v. 9, n. 3-4, p. 299-314, 2007. Available from: https://doi. org/10.1080/15239080701631544. Access on: Mar. 24, 2021.

MEDEIROS, J. B.; TOMASI, C. Redação de artigos científicos: métodos de realização, seleção de periódicos, publicação. São Paulo: Atlas, 2016.

MONASTERSKY, R. Anthropocene: the human age. Nature News, v. 519, n. 7542, p. 144-147, 2015. Available from: https://www.nature.com/news/anthropocene-the-human-age-1.17085. Access on: Sep. 26, 2020.

MOORE, J. W. Capitalism in the Web of Life: ecology and the accumulation of capital. London: Verso Books, 2015.

MOORE, J. W. Introduction. In: MOORE, J. W. (ed.). Anthropocene or Capitalocene? Nature, History, and the Crisis of Capitalism. Oakland, CA: PM Press, 2016.

NATURE. The humanepoch. Editorial. Nature, v.473, p. 254,2011. Availablefrom: https://doi.org/10.1038/473254a. Access on: Sep. 26, 2020.

NEVES, E. G.; PETERSEN, J. B. Political economy and pre-Columbian landscape transformations in Central Amazonia. In: BALÉE, W.; ERICKSON, C. Time and complexity in historical ecology: studies in the neotropical lowlands. Columbia University Press, 2006.

RIVAL, L. Amazonian historical ecologies. Journal of the Royal Anthropological Institute, v. 12, p. S79-S94, 2006. Available from: https://www.jstor.org/stable/3803980. Access on: Sep. 26, 2020.

ROCKSTRÖM, J. et al. Planetary boundaries: exploring the safe operating space for humanity. Ecology and society, v. 14, n. 2, 2009. Available from: http://www.ecologyandsociety.org/vol14/iss2/art32/. Access on: Sep. 26, 2020.

ROOSEVELT, A. C. The Amazon and the Anthropocene: 13,000 years of human influence in a tropical rainforest. Anthropocene, v. 4, p. 69-87, 2013. Available from: https://doi.org/10.1016/j.ancene.2014.05.001. Access on: Sep. 26, 2020.

RUDDIMAN, W. F. The anthropogenic greenhouse era began thousands of years ago. Climatic change, v. 61, n. 3, p. 261-293, 2003. Available from: https://doi.org/10.1023/B:CLIM.0000004577.17928.fa. Access on: Sep. 26, 2020.

RUDDIMAN, W. F. The Anthropocene. Annual Review of Earth and Planetary Sciences, v. 41, p. 45-68, 2013. Available from: https://doi.org/10.1146/annurev-earth-050212-123944. Access on: Sep. 26, 2020.

STEFFEN, W.; CRUTZEN, P.; MCNEILL, J. The Anthropocene: are humans now overwhelming the great forces of nature. Ambio: a journal of the human environment, v. 36, n. 8, p. 614-621, 2007. Available from: https://www. jstor.org/stable/25547826. Access on: Sep. 26, 2020. 
STEFFEN, W. et al. The Anthropocene: conceptual and historical perspectives. Philosophical Transactions of the Royal Society of London A: mathematical, physical and engineering sciences, v. 369, n. 1938, p. 842-867, 2011. Available from: https://doi.org/10.1098/rsta.2010.0327. Access on: Sep. 26, 2020.

STEFFEN, W. et al. The trajectory of the Anthropocene: the great acceleration. The Anthropocene Review, v. 2, n. 1, p. 81-98, 2015. Available from: https://doi.org/10.1177/2053019614564785. Access on: Sep. 26, 2020.

TRISCHLER, H. The Anthropocene: a challenge for the history of science, technology, and the environment. NTM, v. 24, n. 3, p. 309-335, 2016. Available from: https://doi.org/10.1007/s00048-016-0146-3. Access on: Sep. 26, 2020.

VAUGHAN, N. E.; LENTON, T. M. A review of climate geoengineering proposals. Climatic change, v. 109, n. 3-4, p. 745-790, 2011. Available from: https://doi.org/10.1007/s10584-011-0027-7. Access on: Sep. 26, 2020.

VEIGA, J. E. da. Desenvolvimento sustentável: o desafio do século XXI. 3. ed. Rio de Janeiro: Garamond, 2008.

WATERS, C. N. et al. The Anthropocene is functionally and stratigraphically distinct from the Holocene. Science, v. 351, n. 6269, 2016. Available from: https://doi.org/10.1126/science.aad2622. Access on: Sep. 26, 2020.

ZALASIEWICZ, J.etal.The Working Group on the Anthropocene: summary of evidence and interim recommendations. Anthropocene, v. 19, p. 55-60, 2017. Available from: https://doi.org/10.1016/j.ancene.2017.09.001. Access on: Sep. 26, 2020.

ZALASIEWICZ, J. et al. The Anthropocene. Geology Today, v. 34, n. 5, p. 177-181, 2018. Available from: https://doi. org/10.1111/gto.12244. Access on: Sep. 26, 2020. 